\title{
The Strategic Role of Quality Management in the Brazilian Auto Parts Industry: An Empirical Study
}

P.A. Cauchick Miguel, PhD

Núcleo de Gestão da Qualidade \& Metrologia (Quality

Management \& Metrology Group), Methodist University of Piracicaba (UNIMEP), Rod. SP-306, km 1, 13450-000 Santa Bárbara d'Oeste, SP, Brazil, Tel.: +55 (0)19455 2311, ext. 547; Fax: +55 (0)19 455 1361; e-mail: pamiguel@unimep.br

S.R.I. Pires, $D r$

Methodist University of Piracicaba (UNIMEP) and NUMAUSP, Brazil, Tel.: +55 (0)19455 2311, ext. 519;

Fax:+55 (0)19455 1361; e-mail: sripires@sc.usp.br

\begin{abstract}
This paper deals with the current strategic role of the Quality Management in the Brazilian auto parts industry. Since surveys are in the forefront of total quality management, this work presents an empirical study conducted in six Brazilian automotive suppliers operating in the state of São Paulo, Brazil. Aspects of the quality system in the companies surveyed, such as certification, introduction of quality techniques, and assessment of quality costs, are presented. The paper also
\end{abstract}


highlights the strategic role of quality management concerning the automotive industry and points out problems which affects the company manufacturing strategies.

\section{Keywords}

Quality management, quality system, quality certification

\section{INTRODUCTION}

During the 90 's, competition in manufacturing has significantly increased in all over the industrialised regions of the globe. Many industries in the developed countries are now faced with very competitive markets, problems such as over capacity, and new and increasing qualifying criteria for competition. In the newly industrialised nations many companies are now dealing with the reality of an open economy and the challenges of global competition. In both situations, old manufacturing paradigms and practices are no longer enough to meet the high level of competition. Even for the current leading-edge companies or 'lean organisations' it is not possible to assure a long term solid position in the market place. External and internal reasons for discontinuities and new customers expectations have continually threaten established market positions.

In the past four decades or so, automotive has been recognised as one of the most competitive industry of the world, and has driven most innovations in the entire industry. In the last two decades, competition in the sector increased significantly through the world, and Just-in-time production has become as a qualifying criteria for competition. Recently, automotive manufacturers have demanded a morc involvement with the auto parts suppliers in new plants worldwide, rationalised the supply base, defined a new set of supply requirements (such as global sourcing, full service supply and design and design for manufacturing/assembly techniques), and have outsourced part of their traditional activities, mainly in an attempt to decrease production costs and increase the speed of the development of new products (Collins et al., 1997). Additionally, product quality has consolidated as a key factor for the auto parts industry competitiveness.

This situation are present in several market places; from developed nations to emerging economies. In Brazil for example, after a long period of protection, high inflation, and economic stagnation, automotive manufacturers are now faced with a new and distinct competitive environment. The most significant change began early in the 1990s with a change of government and the beginning of a process of economic liberalisation, followed by the implementation of Mercosul (or SAFTA South America Free Trade Agreement) which created a common market between Brazil, Argentina, Uruguay and Paraguay. A more recent achievement in this 
sequence of events was a major reduction in inflation, from over $50 \%$ to less than $1 \%$ per month, which has increased the importance of manufacturing activities, since that during the long period of high inflation there was a relatively heavy emphasis on financial activities. The stabilisation and liberalisation plan has been relatively successful, a fact that resulted in the growth in industrial activity and especially in the return of foreign investments. Along with other industries of developed countries, the Brazilian automotive industry has recently experienced a boom in investments, after 15 years of economic stagnation. Approximately US\$ 18 billion will be invested in Brazil until the year 2000, coming from companies already installed in the country and from those currently in the process of setting up operations there. The forecast is to produce 2.5 million units a year in 2000 , 500,000 of which will be for export. This means that Brazil shall become 6th in the world production ranking, coming after the US, Japan. Germany, France and South Korea. Moreover, new experiments in the automotive industry has been implemented in the country, such as the revolutionary modular consortium model (Pires, 1998).

This paper deals with the current strategic role of the Quality Management in the Brazilian auto parts industry and presents an empirical study conducted in seven Brazilian automotive suppliers operating in the state of São Paulo. It also discusses the strategic role of quality management concerning the automotive industry and points out problems which affects the company manufacturing strategies.

\section{THE STRATEGIC ROLE OF QUALITY MANAGEMENT IN THE AUTOMOTIVE INDUSTRY}

From the manufacturing strategy perspective, and using the well-disseminated approach of Hill (1993), Quality has performed two important role in the entire industry in the last decades: a qualifier criteria for competition, and an element of product differentiation (as a winner-order criteria). In this sense, companies all over the world have sought certification, implemented quality programmes, and applied TQM practices. For example, ISO certification is becoming a common denominator for business management standards worldwide (European Quality, 1996). More importantly, the quality movement, started by the Japanese, has taken a strategic role in the manufacturing industry. Since the early 70 's, Japanese car automakers have achieved high levels of penetration in US and European markets so that the companies in Western countries have pursued better product quality with lower costs, becoming a strong need to the company's competitiveness. In parallel, just-in-time (JIT) techniques have become wellapplied leading to a necessity of establishing a supplier qualification process to assure quality in the just-in-time deliveries within the automotive industry supply chain. 
Recently, the automotive manufacturers are going beyond JIT practices. They are restructuring and consolidating the supply base through a reduction of number of suppliers and increasing the requirements in the partnership in a global market. As reported by the Brazilian Auto Parts Association (Abipeças), the Brazilian auto part market is currently split between $70 \%$ local suppliers and $30 \%$ outside suppliers, but this situation will invert in the next few years. Moreover, the automotive suppliers have conducted movements towards the reduction of number via merges, adjustments and improvements to support the new level of requirements. For example, Abipeças had 550 members in 1996 but expects to have only 250 in 1998 . It seems essential to make diagnostic assessments of aspects related to Quality as a one of company priorities within its manufacturing strategy. Therefore, this paper presents some results of an exploratory study carried out in sample of Brazilian companies, described below.

\section{AN EMPIRICAL STUDY OF QUALITY IN THE BRAZILIAN AUTO PARTS SUPPLIERS}

In a new scenario of high competitiveness, automotive suppliers have introduced a number of initiatives to stimulate growth in manufacturing industry. Among these initiatives, the introduction of quality systems, ISO 9000 series and TQM (Total Quality Management) programmes are strategic to the present Brazilian industrial development. In the early 90's, the Brazilian government launched the 'National Programme of Quality and Productivity' which has contributed to fundamental changes in the enterprises faced with the global market. This programme suggests mechanisms to improve the quality of products and management at international levels. Since then, there has been a remarkable enhancement in manufacturing productivity and industrial quality.

The number of ISO 9000 certified companies has been increasing in Brazil. For example, there were about 400 certified Brazilian companies in 1994, increased to approximately 1600 in 1996 , and there are now more than 2100 companies holding ISO 9000 certification (until September 1997).

In this context, this paper presents a pilot study of industrial quality systems which has been conducted with six autoparts companies. The participants in the survey are shown in Table 1. The name of the companies were omitted to ensure complete confidentiality.

The survey was applied through a questionnaire and interviews with quality and plant managers of these automotive suppliers. The questionnaire contained fifteen questions divided into four sections, including company data (such as number of employees, annual sales, and type of product produced by them). Other sections were concerned with company quality system and certification, application of quality techniques and tools, and assessment of quality costs. The findings are presented below. 
Table 1 Companies Surveyed

\begin{tabular}{cclc}
\hline Company & $\begin{array}{c}\text { Staff } \\
\text { (approx.) }\end{array}$ & \multicolumn{1}{c}{ Main Products } & $\begin{array}{c}\text { Annual Sales } \\
\text { (£ Million) }\end{array}$ \\
\hline A & 1900 & Conventional and ABS brake systems & 181.9 \\
B & 1300 & Air cleaners and fuel filters & 62.5 \\
C & 500 & Hoses for fuel and cooling systems & 21.2 \\
D & 500 & Batteries and dash board wires & not available \\
E & 500 & Speakers and twitters & 22.5 \\
F & 500 & Radiators & 75 \\
\hline
\end{tabular}

\section{RFSULTS}

The results from this pilot study have shown that all companies surveyed has a quality system implemented. However, the period for this implementation varies from before 1985 to the present time. Furthermore, it is unanimous that there are resources specifically set aside for quality improvement because of either OEM demands or choice of quality as a competitive priority.

\subsection{Quality System Certification}

Regarding certification, nearly $70 \%$ are ISO 9001 certified. The remaining companies are presently in the process of auditing to get certification. Additionally, only two companies are certified according to QS 9000, which is a rather recent process in Brazil (Cauchick Miguel, 1998a). It is estimated that the direct suppliers of Ford, General Motors, and Chrysler in Brazil are approximately 450 of which $30 \%$ are certified by ISO 9000 series. Currently, there are very few Brazilian companies which comply with QS 9000, such as Meritor-Fumagalli (steel wheels), ITT Automotive (brake systems), Usiminas (steel), Freios Varga (brake systems), Valeo (radiators), and a plant of Ford Brasil (casting paris). The number of companies is, however, increasing significantly. Others in process of certification are Goodyear, Pirelli, Cosipa, Valeo, Delphi, to name but a few. A more detailed study regarding QS 9000 certification in one of the first Brazilian companies is presented elsewhere (Cauchick Miguel, 1998b).

There are, in fact, some problems when implementing a quality system for QS 9000 certification. Among them, it can be named: lack of experience with a new standard (including the registrars), the involvement of the top management, problems when applying a new quality technique (e.g. FMEA), insufficient definitions in the standard (e.g. 'Servicing Element'), and how the certification problems reflects in the company manufacturing strategies. 


\subsection{Application of Quality Techniques}

The use and application of quality techniques were also been investigated. The respondents were given options to answer the questions exploring the application of quality techniques, such as FMEA (Failure Mode Effects Analysis), FTA (Fault Tree Analysis), QFD (Quality Function Deployment), SPC (Statistical Process Control), DoE (Design of Experiments), VA (Value Analysis), Taguchi techniques, and after-sales monitoring. The results can be seen in Figure 1.

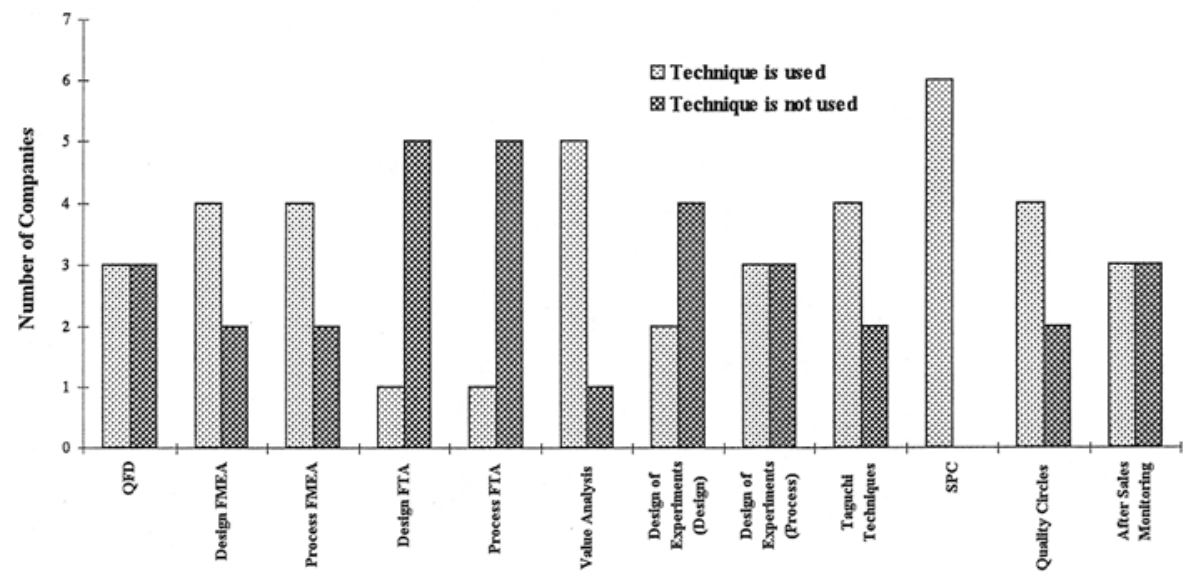

Figure 1 Application of quality techniques and principles.

These results showed in Figure 1 demonstrated that there are several techniques which are not well applied. For example, either design or process FTA is used in only one company. On the other hand, there are techniques, like SPC, which all of companies surveyed use. In the middle ground, there are others, such as QFD, DoE, and after sales monitoring, which are applied in half of the companies. It is worth mentioning that several of these techniques are not fully implemented, according to information supplied by the quality and plant managers.

\subsection{Assessment of Quality Costs}

This section was concerned to indicate what types of quality costs are assessed, divided into the categories of Prevention, Appraisal, and Failures. Nearly all of the companies surveyed assess only failure costs, represented by scrap or losses, and cost of re-work. Although the companies stated that they have an after-sales monitoring system, they did not mention assessment of external failure costs. Few companies indicated appraisal costs (inspection) and only one pointed out that it assesses prevention costs. These results are summarised in Figure 2. 


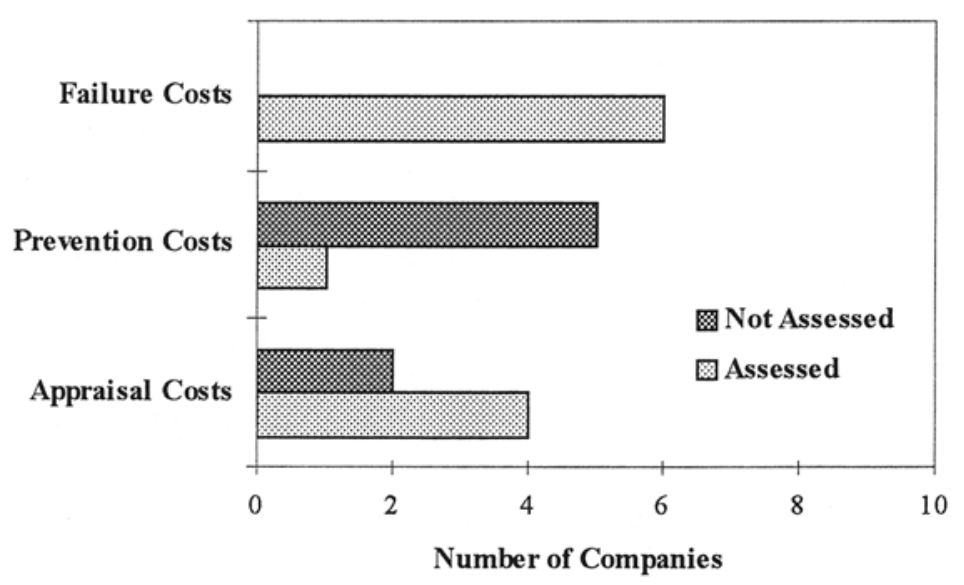

Figure 2 Assessment of Quality Costs.

\section{CONCLUDING REMARKS}

The political instability, high inflation, and economic recession in Brazil during the 80 's and beginning of 90 's practically blocked the country process of modernisation and adoption of new technologies. Currently, the scenario has changed, and the Brazilian automotive industry has rapidly reacted to these changes. For most companies, there is an expectation that new standards of quality will bring the country to high levels of competitiveness in a global market. It is important to emphasise that the response among the Brazilian manufacturing companies faced with the current standard of competitiveness has not been a totally homogeneous adjustment. The efforts and adaptations are more clearly visible in the companies already established in the global context of competitiveness, considering Quality Management as a key factor of manufacturing performance. In this context, Quality has played an important role and has quickly become a new forefront for companies interested in competitive advantages in the marketplace. The pilot study suggested that new Quality practices have been implemented in a competitive context characterised by the existence of a new set of competitive needs, which have introduced new barriers and standards for competition, mainly stressed by the conciliation of higher quality with lower production costs. This environment of hyper competition has demanded a clear definition of company focus and priorities, as well as the development and maintenance of distinctive competencies within the product demand chain. Further work will concentrate in enhancing the survey both in terms of revising the methodology (questionnaire and data collection) and expanding the number of companies surveyed (increase the sample). 


\section{REFERENCES}

Cauchick Miguel, P.A. (1998a) Quality Certification in Brazil: From ISO 9000 to QS 9000. Paper accepted for publication in the Quality World Journal, (November issue).

Cauchick Miguel, P.A. (1998b) A Case Study on QS 9000 Certification in a Brazilian Company. Paper accepted for presentation in the Conference of Canadian Society for Mechanical Engineering, Toronto, Canada, 19-22 May.

Collins, R.S.; Bechler, K.; Pires, S.R.I. (1997) Outsourcing in the Automotive Industry: From JIT to Modular Consortia, European Management Journal, 15(5), 498-508.

Hill, T. (1993) Manufacturing Strategic Management of the Manufacturing Function", Open University Set Book, London.

Pires, S.R.I. (1998) Managerial Implications of the Modular Consortium model in a Brazilian Automotive Plant, International Journal of Operations \& Production Management, 18(3) (forthcoming).

Standard Continues its Rise (1996) European Quality, 3(6), 12-14.

\section{BIOGRAPHY}

Paulo A. Cauchick Miguel graduated in Industrial Engineering in 1986. He then worked as a manufacturing engineer for Bendix of Brazil (former Allied Automotive group; now Bosch Brake Systems Co.) and Varga (a former Lucas partner, now $100 \%$ Lucas control), until 1990 when he became a lecturer in the Technology Centre at the Methodist University of Piracicaba (UNIMEP). He holds a Master of Science in Mechanical Engineering from State University of Campinas (1992), and finished his $\mathrm{PhD}$ in Manufacturing Engineering at the University of Birmingham, UK, in 1996. Now he is heads the Quality Management Research Group at the UNIMEP.

Sílvio R. I. Pires is a Professor of Manufacturing Management at the Methodist University of Piracicaba (UNIMEP) and a Researcher of NUMA-USP (University of São Paulo) in Brazil. He worked five years for Villares-General Electric Equipment as a Manufacturing and Control Manager, and has an undergraduate's, Master's and Doctorate degree in Production Engineering. During 1996, he was a Research Associate Professor at IMD in Switzerland. 